DOI https://doi.org/10.36059/978-966-397-210-7/229-256

Крестовська Н. М., доктор юридичних наук, професор, професор кафедри морського права Національного університету «Одеська морська академія», м. Oдеса

\title{
Матвєєва Л. Г.,
}

доктор юридичних наук, доцент, завідувач кафедри теорії та філософії права

Одеського державного університету внутрішніх справ, м. Oдеса

\section{ОСОБИСТІ ПРАВА ЛЮДИНИ ПЕРШОГО ПОКОЛІННЯ В НАЦІОНАЛЬНОМУ, РЕГІОНАЛЬНОМУ ТА МІЖНАРОДНОМУ ВИМІРІ}

Анотація. Урозділі особлива увага приділена особистим правам, що належать до першого покоління прав людини, таким як: право на життя; право на вільний розвиток; право на повагу людської гідності; право на свободу і особисту недоторканність у національному, регіональному та міжнародному виміри. Дано визначення особистих прав і свободи людини. Розкрито зміст права на життя та еволюцію його закріплення на універсальному, регіональному та національ-ному рівні. Названі основні обов'язки держави в забезпеченні реалізації права людини на розвиток. Розкрито зміст та права на свободу і особисту недоторканність. Зміст, сутність та характеристики зазначених права людини розглянуто крізь призму практики Європейського суду із прав людини.

\section{Вступ}

Особисті права людини, що належать до першого покоління прав людини, неодноразово ставали об'єктом 
Права людини в Україні та у зарубіжних країнах:

проблеми теорії та нормативно-правової регламентації

дослідження у вітчизняній науці1. Значна увага приділена цьому масиву прав людини у навчальній літературі². Разом із тим невичерпність ідеї прав людини та постійний розвиток практики їх реалізації, захисту та охорони зумовлюють необхідність подальшої розробки цієї проблеми.

Концепція прав першого покоління прав людини початково полягала в тому, що саме так було позначено основні ліберальні цінності, проголошені в ході буржуазних революцій в Європі (особливо під час Великої Французької революції) і становлення США як незалежної

1 Див. Антонович М. Україна в міжнародній системі захисту прав людини: монографія. Київ : Видавничий дім «КM Academia», 2000. 262 с.; Кожан В.В. Особисті права людини: загальнотеоретична характеристика: дис. ... канд. юрид. наук: 12.00 .01 - теорія та історія держави і права; історія політичних і правових учень. Львів, 2016. 229 с.; Пушкіна 0. Особисті права людини в конституційному законодавстві України. Юридична Україна. 2013. № 5. С. 17-24; Рабінович П.М. Основоположні права людини: соціально-антропна сутність, змістова класифікація. Вісник Національної академіі правових наук України. 2013. № 2 (73). С. 10-15; Размєтаєва Ю.С. Права людини як фундаментальна цінність громадянського сус-пільства: монографія. Харків : Финарт, 2013. 196 с.; Шукліна Н.Г. Конституційно-правове регулювання прав і свобод людини і громадянина в Україні (питання теорії і практики) : монографія. Київ : Центр навчальної літератури, 2005. 424 с.

2 Див. Бисага Ю.М., Палінчак М.М., Бєлов Д.М., Данканич М.М. Права людини. Ужгород, 2003. 189 с.; Рабінович П.М., Хавронюк М.I. Права людини і громадянина: навч. посібник. Київ : Атіка, 2004. 464 с.; Права і свободи людини і громадянина в Україні (доктрина Європейського суду з прав людини і Конституційного Суду України) : навчальний посібник / звернення до читачів Голови Конституційного Суду України (VII.2010-VII.2013 роки) Головіна А.C. ; вст. слово і заг. ред. проф. Мартиненка П. Ф., Кампа В. М. Київ : Юрінком Інтер, 2013. 376 с.; Размєтаєва Ю.С. Доктрина та практика захисту прав людини: навчальний посібник. Київ: ФОП Голембовська 0.О., 2018. 364 с.; Проблеми сучасної конституціоналістики: навч. посіб. / за заг. ред. А.Р. Крусян та А.А. Єзерова. Київ: Юрінком Інтер, 2018. 524 с. (Серія «Проблеми сучасної конституціоналістики». Вип. 4: Конституційне гуманітарне право). 
держави (XVII-XIX століття). Такими цінностями було визнано: життя, свободу із засобами набуття і володіння власністю, прагнення до щастя і безпеки (Декларація прав Вірджинії 1776 р.), життя, свободу та прагнення до щастя (Декларація незалежності США 1776 р.); свободу, власність, безпеку, опір гнобленню (французька Декларація людини і громадянина 1789 р.).

Права першого покоління $є$ основою інституту прав людини. За словами К. Веллмана, одне покоління прав людини практично повністю складається 3 «батьків» наступного покоління ${ }^{3}$. У цьому сенсі перше покоління $€$ прабатьком усіх наступних поколінь прав людини.

Поняття «поколінь прав людини», уведене до наукового обігу сорок років тому, з тих пір набуло, крім значення історичного генезису прав людини, властивостей критерію класифікації прав людини: згадуючи перше покоління прав людини, ми маємо на увазі, перш за все, особисті та політичні права. Цей розділ монографії присвячено основоположним особистим правам людини, на забезпечення реалізації яких, по суті, спрямовано усі інші покоління прав людини.

У новітній час ці права знайшли своє відображення в конституціях і законах більшості країн світу, а також в міжнародних документах. Серед них особливе місце займають Всесвітня Декларація прав людини (далі ВДПЛ) і Міжнародний пакт про громадянські і політичні права (далі - МПГП). Механізми захисту прав першого покоління на регіональному рівні представлені Радою Європи та Європейським судом із прав людини, які діють відповідно до Конвенції про захист прав людини та основоположних свобод (далі - КЗПЛ) і Додатковими протоколами до неї. На національному рівні права людини першого покоління, а саме - життя і здоров'я,

3 Wellman C. Solidarity, the Individual and Human Rights. Human Rights Quarterly. 2000. Volume 22, Number 3. P. 641. 
честь і гідність, недоторканність і безпеку визнано властивостями людини, які зумовлюють ії найвищу соціальну цінність (стаття 3 Конституції України).

\section{1. Право на життя: поняття, зміст, нормативне закріплення}

Право на життя - це право на існування людини як біологічної, соціальної та духовної істоти, гарантоване об'єктивним правом.

Змістом права на життя $\epsilon$ такі основні правомочності:

1) право на продовження біологічного існування;

2) право на захист свого життя від неправомірних посягань та від інших загроз життю;

3) право на визначення способів та шляхів існування, які не порушують права інших людей на життя.

На універсальному рівні право на життя вперше було проголошено Всесвітньою Декларацією прав людини [4] 1948 року і підтверджено Міжнародним Пактом про громадянські та політичні права [10] 1966 року (стаття 6), на європейському регіональному рівні - КЗПЛ (стаття 2) [6], на національному рівні - закріплено Конституцією України (стаття 27) [7].

Конституція України закріплює право на життя за допомогою заборони свавільного (незаконного) позбавлення життя. Верховна Рада України скасувала кримінальне покарання у вигляді смертної кари. Отже, ніхто не може бути позбавлений життя навіть за рішенням суду. Другий важливий компонент закріплення права на життя - право людини на самозахист від протиправних посягань на життя і здоров'я.

Але право на життя, всупереч висловлюваній у деяких дослідженнях думці [5], не $\epsilon$ абсолютним. Згідно із частиною 2 статті 2 КЗПЛ позбавлення життя не розглядається як правопорушення 3 боку індивіда або держави, якщо воно є наслідком виключно необхідного застосування сили: 
1) для захисту будь-якої особи від незаконного насильства;

2) для здійснення законного арешту або для запобігання втечі особи, яку законно тримають під вартою;

3) під час вчинення правомірних дій для придушення заворушення або повстання.

Крім того, положення статті 2 Конвенції не поширюються на випадки смерті внаслідок правомірних воєнних дій (частина 2 статті 15 Конвенції).

Отже, захист від незаконного насильства має бути правомірним, достатнім і обгрунтованим. Застосування сили, що спричинило смерть людини, має бути абсолютно необхідним для досягнення однієї з вказаних цілей і має бути пропорційним відвернутій загрозі охоронюваним інтересам. Такі вимоги закріплено в конституціях сучасних держав, кримінальному та кримінально-процесуальному законодавстві.

Праву людини на життя відповідає низка обов'язків держави та інших суб'єктів публічної влади:

заборона свавільного позбавлення життя. Попри рекомендаційну норму МПГП, у багатьох країнах світу досі існує такий вид покарання, як смертна кара. Утім, Пакт вимагає, аби смертні вироки виносилися тільки за найтяжчі злочини відповідно до закону, який діяв під час вчинення злочину і який не суперечить постановам Пакту і Конвенції про запобігання злочинові геноциду і покарання за нього. Смертний вирок не повинен виноситися за злочини, вчинені неповнолітніми, молодшими за вісімнадцять років, і не має виконуватися щодо вагітних жінок.

Ставлення до смертної кари в європейському правовому просторі можна назвати динамічним. Початково КЗПЛ лише обмежувала ії: «Нікого не може бути умисно позбавлено життя інакше ніж на виконання смертного вироку суду, винесеного після визнання його винним у вчиненні злочину, за який закон передбачає таке покарання» (частина 1 статті 2). Протокол № 6 до КЗПЛ (1983) зобов'язав держави-учасниці скасувати смертну 
кару як покарання, зробивши виняток для застосування їі за діяння, вчинені під час війни або невідворотної загрози війни [14]. Нарешті, Протокол № 13 до Конвенції про захист прав людини і основоположних свобод (2002) зобов'язав держави-учасниці Конвенції скасувати смертну кару у всіх випадках [13]. На сьогодні тільки одна країна член Ради Європи - зберігає цей вид покарання, але не застосовує на практиці (Російська Федерація).

Національне законодавство України імплементувало норми, зазначені у вищенаведених міжнародно-правових актах. Стаття 27 Конституції України визначає невід'ємне право кожної людини на життя, право на захист свого життя й життя іншої людини та обов'язок держави захищати життя людини. Рішенням КСУ у справі про смертну кару № 11-рп/99 від 29 грудня 1999 року визначено, що смертну кару як вид покарання не можна вважати винятком із невід'ємного права на життя кожної людини, закріпленого в Конституції України, що знайшло відображення у системі кримінальних покарань, де таке покарання відсутнє [21].

Слід також відмітити, що на сьогодні існує низка проблемних питань, пов'язаних із правом людини на життя, до основних з яких слід віднести: право на штучне переривання вагітності та штучне запліднення, правовий режим здійснення дослідів у галузі ембріології та правовий статус ембріона, питання про правомірність клонування людини, проблеми застосування евтаназії; застосування сили, яка загрожує життю людини з урахуванням вимог абсолютної необхідності та пропорційності.

Держава зобов'язана забезпечити професійну підготовку осіб, що задіяні в охороні правопорядку, аби мінімізувати ризики заподіяння смерті під час виконання ними службових обов'язків..

Критерії абсолютної необхідності пропорційності рельєфно виражено у справах «МакКанн та інші проти Великої Британії» (McCann and others v. the United Kingdom, 
1995) [29] та «Гюлек проти Туреччини» (Gulec v. Turkey, 1998) [39], розглянутих ЄСПЛ.

Фабула першої справи $\epsilon$ такою. Британська розвідка встановила, що Ірландська республіканська армія (IRA) готує терористичний акт на території Гібралтара, причому було встановлено особи ймовірних виконавців. Задля попередження планованого вибуху замінованого автомобілю було вирішено арештувати підозрюваних до вчинення ними теракту. Під час затримання військовослужбовці були уведені в оману жестами підозрюваних, які простягнули руки до внутрішніх кишень/сумочки (одна з підозрюваних була дівчиною). Серією пострілів усі підозрювані були вбиті. При них не було ані зброї, ані вибухівки (правда, вибухівка була в авто, яке підозрювана Фаррелл орендувала на чуже ім'я). Суд встановив, хоча й не одноголосно, порушення статті 2 КЗПЛ. При цьому Суд зазначив, що застосована сила має бути «абсолютно необхідною» для досягнення однієї 3 цілей, викладених у підпунктах (a), (b) i (c) частини 2 статті 2 КЗПЛ, що означає необхідність суворої та ретельної перевірки обставин, за яких застосовується сила, причому необхідно враховувати не тільки дії представників держави, які реально застосовують цю силу, але також і всі супутні обставини, включаючи такі питання, як планування можливих дій і контроль за ними.

По другій справі Судом було встановлено, що під час контртерористичної операції, що проводилася турецькими правоохоронцями 4 березня 1991 р. у місті Іділ, був застрелений 15-річний Ахмед Гюлек, який випадково опинився на місці події. Суд встановив обов'язок держави охороняти право на життя й відповідальність держави за відсутність критичної оцінки обставин, за яких було застосовано зброю, необгрунтоване застосування сили та відсутність об’єктивного розслідування причин смерті Ахмеда Гюлека. 


\section{2. Право на вільний розвиток: поняття, обов'язки держави по його забезпеченню}

Кожна людина має право сама визначати свою долю, ставити перед собою визначені нею самою цілі, обирати засоби для досягнення цих цілей. Саме таким $є$ зміст права на щастя, що відноситься до першого покоління прав людини. У сучасному розумінні право на щастя чи прагнення до щастя набуло характеру права людини на розвиток своєї особистості. Людський розвиток - це процес розширення вибору способу життя для людини. Насамперед це: вести здоровий спосіб життя і жити довго, набувати знань, мати ресурси, аби підтримувати належний життєвий рівень. Сюди ж належать політична, економічна і соціальна свободи, можливість займатися творчою та виробничою діяльністю. Але, зрозуміло, право на вільний розвиток не $є$ безмежним: обираючи свій шлях розвитку, людина не повинна порушувати прав інших людей.

Право на розвиток не зафіксовано у ВДПЛ, але воно набуває все ширшого визнання та підтримки світовим співтовариством. У 1986 року ООН прийняла «Декларацію про право на розвиток» [3], якою було започатковано роз'яснення змісту цього права. Право на розвиток $\epsilon$ невід'ємним правом людини, в силу якого кожна людина і всі народи мають право брати участь у такому економічному, соціальному, культурному та політичному розвитку, за якого можуть бути повністю здійснені всі права людини та основні свободи, а також сприяти йому та користуватися його благами (стаття 1 ).

Принципово важливим $\epsilon$ положення статті 2 Декларації про те, що людина є основним суб'єктом процесу розвитку та має бути активним учасником і бенефіціаром права на розвиток. Право людини на розвиток одночасно означає обов'язок поважати права і свободи інших людей, а також виконувати певні обов'язки перед суспільством. Оскільки лише суспільство спроможне забезпечити вільний 
розвиток людини, люди мають захищати правовий порядок, необхідний для їх розвитку.

Основні обов'язки в забезпеченні реалізації права людини на розвиток Декларація покладає на державу. Держави:

- несуть основну відповідальність за створення національних i міжнародних умов, сприятливих для здійснення права на розвиток;

- мають здійснювати в індивідуальному і колективному порядку заходи, спрямовані на розроблення політики в галузі міжнародного розвитку 3 метою сприяння здійсненню в повному обсязі права на розвиток;

- мають вживати рішучих заходів, спрямованих на ліквідацію масових і грубих порушень прав людини народів i осіб, які стикаються із ситуаціями, що $\epsilon$ результатом апартеїду, всіх форм расизму i расової дискримінації, колоніалізму, іноземного панування i окупації, агресії, іноземного втручання і загроз національному суверенітету, національної єдності і територіальної цілісності, загрози війни і відмови визнати основоположне право народів на самовизначення;

- мають співпрацювати з метою сприяння, заохочення і зміцнення загальної поваги і дотримання всіх прав людини і основних свобод для всіх незалежно від раси, статі, мови або релігії;

- мають сприяти встановленню, підтримці і зміцненню міжнародного миру і безпеки і з цією метою докладати всіх зусиль для досягнення загального і повного роззброєння під ефективним міжнародним контролем, а також для забезпечення використання вивільнюваних в результаті прийняття ефективних заходів щодо роззброєння коштів із метою всебічного розвитку, зокрема країн, що розвиваються;

- на національному рівні мають вживати необхідних заходів для здійснення права на розвиток, забезпечувати рівність можливостей для всіх у тому, що стосується доступу до основних ресурсів, до освіти, охорони здоров'я, харчування, житла, зайнятості, справедливого розподілу 
доходів, забезпечення активної ролі жінок у процесі розвитку, проведення економічних і соціальних реформ.

Надзвичайно важливим $\epsilon$ те, що в Декларації право народів і держав на розвиток сформульоване в нерозривній єдності з їхнім правом на мир, самовизначення, суверенітет над природними, багатствами i ресурсами. Із змісту Декларації випливає весь комплекс основних прав, що становлять «третє покоління» прав людини (права народів). Це такі права, як право народів на мир, на самовизначення, на суверенітет над природними багатствами, на здорове і чисте довкілля, на загальну спадщину людства. Разом із правом на розвиток ці права відкривають перед людством широкі можливості і перспективи для забезпечення індивідуальних і корпоративних прав людини.

Право на розвиток у Конституції України сформульовано в тісному зв'язку з обов'язками людини: «Кожна людина має право на вільний розвиток своєї особистості, якщо при цьому не порушуються права i свободи інших людей, та має обов'язки перед суспільством, в якому забезпечується вільний і всебічний розвиток ії особистості» (стаття 23).

Основне завдання держави полягає в тому, щоби створити найкращі умови і соціально-економічні засади для реалізації цього права, що випливає зі статті 3 Конституції України, за якою права і свободи людини та їх гарантії визначають зміст і спрямованість діяльності держави. Держава, по-перше, має відкрити для кожної людини якомога більше сфер для розвитку власної особистості, по-друге - запобігати порушенням цього права, по-третє - усувати перешкоди для реалізацією людиною свого потенціалу. Право на розвиток тісно пов'язане ыз правами на працю, на освіту та іншими культурними правами. Здійснення державою своїх позитивних обов'язків як гарантій реалізації права людини на розвиток включає створення особливих умов для тих осіб, які з об’єктивних причин самостійно не можуть або 
Права людини в Україні та у зарубіжних країнах:

проблеми теорії та нормативно-правової регламентації

відчувають складнощі у доступі до навчання, до виробничої чи творчої діяльності.

\section{3. Право на повагу людської гідності: зміст та міжнародний, європейський, національний механізми запобігання посягань на гідність людини}

Людська гідність, на переважаючу думку науковців, $є$ витоком усіх прав людини, що випливають із самої природи людини. Людська гідність - це те, що вирізняє людину серед інших явищ оточуючого нас світу У цьому плані зміст цього поняття $\epsilon$ близьким до поняття «людяність», яке П.М. Рабінович визначає як біологічні, психічні, соціальні властивості людини, що відрізняють ії від усіх інших живих істот 4 .

Право на повагу людської гідності - це юридичне закріплення природно-правової категорії людської гідності, яке зумовлює відповідні обов'язки як людини, так і публічної влади, щодо його дотримання та забезпечення. Зміст цього юридичного права розкривається i забезпечується встановленням заборон на дії, що посягають на людську гідність, а саме: катування, жорстоке, нелюдське та таке, що принижує гідність, поводження або покарання, примусові медичні або наукові дослідження на людині без її вільної згоди.

На міжнародному рівні право на повагу людської гідності передбачено статтею 5 ВДПЛ, яка наголошує, що ніхто не повинен зазнавати катувань, або жорстокого, нелюдського, або такого, що принижує його гідність, поводження і покарання, і підтверджено МПГП (стаття 7), на європейському регіональному рівні - КЗПЛ (стаття 3), на національному рівні - закріплено Конституцією України (стаття 28).

4 Див. Грищук О.В. Людська гідність у праві: філософські проблеми. Львів: ЛДУВС, 2007. С. 376; Рабінович П. М. Людяність як об'єкт правового захисту (до 65-річчя завершення Нюрнберзького процесу). Бюлетень Міністерства юстицї України. 2011. № 10. С. 52. 
Зміст понять «катування» розкривається в Конвенції проти катувань та інших жорстоких, нелюдських або таких, що принижують гідність, видів поводження і покарання 1984 р. (на сьогодні учасницями Конвенції є 165 держав). Катування означає будь-яку дію, якою будь-якій особі навмисне заподіюються сильний біль або страждання, фізичне чи моральне, щоб отримати від неї або від третьої особи відомості чи визнання, покарати ії за дії, які вчинила вона або третя особа чи у вчиненні яких вона підозрюється, а також залякати чи примусити ії або третю особу, чи 3 будь-якої причини, що грунтується на дискримінації будьякого виду, коли такий біль або страждання заподіюються державними посадовими особами чи іншими особами, які виступають як офіційні, чи 3 їх підбурювання, чи 3 їх відома, чи за їх мовчазної згоди. У визначені «катування» звертають на себе увагу три елементи:

1) умисний характер заподіяння болю або страждання,

2) мета, 3 якою вони заподіюються (отримання відомостей чи визнання провини, покарання, залякування),

3) особа, що заподіює цей біль або страждання (державна посадова особа).

Цей термін не охоплює біль або страждання, що виникли внаслідок застосування правових санкцій, дій, нерозривно пов'язаних із цими санкціями або випадково викликаних цими санкціями. Наприклад, не $\epsilon$ катуванням застосування фізичної сили чи спеціальних засобів під час затримання особи, яка намагається втекти 3 місця вчиненого нею злочину.

Крім терміна «катування», Конвенція ООН проти катувань не дає визначення інших видів неправового поводження або покарання. Тому ЄСПЛ, розглядаючи скарги про порушення заборони катувань, а також нелюдських або таких, що принижують гідність, видів поводження чи покарання, самостійно розмежував ці поняття.

Дії посадових осіб держави щодо особи, які кваліфікуються як катування, нелюдське поводження чи 
покарання, поводження чи покарання, що принижує гідність, становлять порушення статті 3 Конвенції про захист прав людини та основоположних свобод у разі, якщо вони сягають хоча би мінімального рівня жорстокості. У рішенні у справі «Ірландія проти Великої Британії» (Ireland v. the United Kingdom від 18.01.1978) [38] суд зазначив, що «оцінка мінімального рівня жорстокості має відносний характер; вона залежить від усіх обставин справи, таких як тривалість даного поводження, його фізичні та психічні наслідки, а в деяких випадках - стать, вік, стан здоров'я потерпілого та інші обставини».

ЄСПЛ надає таке розмежування катування та нелюдського чи такого, що принижує гідність, поводження. Катування свідчить про намір надати особливої ганебності умисному нелюдському поводженню, яке спричиняє дуже тяжкі й жорстокі страждання. На додаток до жорстокості поводження ознакою катування $є$ також наявність мети такого поводження, як це визнано в Конвенції ООН проти катувань та інших жорстоких, нелюдських або таких, що принижують гідність, видів поводження і покарання.

Принципи оцінки рівня жорстокості за критеріями ЄСПЛ:

- індивідуальні характеристики потерпілого - його вік, стать, а також його зв'язок із тим, хто завдає йому страждань (зокрема, співвідносність фізичної сили потерпілого 3 фізичною силою особи, яка здійснює затримання чи арешт особи). Так, у рішенні у справі «Корнейкова та Корнейков проти України» [27] від 24.06.2016 Суд визнав порушення статті 3 Конвенції у зв'язку із застосуванням до заявниці в пологовому будинку наручників та у зв'язку з побутовими умовами її тримання у Харківському СІ30;

- межі страждань, зазнавши яких, людина вважається такою, що іï піддали поводженню, забороненому статті 3 КЗПЛ. Нижньою межею страждань уважаються моральні страждання. Так, у рішенні у справі «Yankov v. Bulgaria» [24] від 11.12.2003 Суд зазначив, що примусове гоління голів у 
осіб, які перебувають під вартою, може принижувати їхню людську гідність, породжувати відчуття скривдження й підкорення. Верхньою межею страждань, яких зазнає людина внаслідок порушення статті 3 Конвенції про захист прав людини та основоположних свобод, $\epsilon$ катування. Так, у справі «Aydin v. Turkey» [37] від 25.09.1997 Суд встановив, що побиття, мордування та зґвалтування поліцейськими заявниці, ще й поєднане із психічним насильством, становить порушення статті 3 КЗПЛ і досягає рівня катування.

Поводження чи покарання, що принижують людську гідність, $€$ поводженням, що «спричиняє в потерпілого почуття страху, болісні страждання й почуття неповноцінності, спроможні принизити його гідність i навіть зламати його фізичний і моральний опір» (рішення Суду у справах «Ireland $V$. the United Kingdom» від 18.01.1978).

Нелюдське поводження чи покарання має такі ознаки: умисне застосування фізичного чи психічного насильства щодо особи або невжиття певних заходів, його тривалість (як мінімум впродовж кількох годин поспіль) і як наслідок- тілесні ушкодження або гострі фізичні чи душевні страждання навіть без мети отримання від особи певних відомостей (рішення у справі «Kudla V. Poland» від 26.10.2000). Так, у рішенні у справі «Öcalan v. Turkey» від 12.05.2005 Суд визнав наявність нелюдського поводження 3 огляду на те, що особа незаконно була піддана стражданням від страху бути страченою.

Нелюдське ж покарання може виявлятися у формі одиночного тримання під вартою особи, оскільки «суцільна сенсорна ізоляція, поєднана зі суцільною соціальною ізоляцією, може знищити особистість». Проте лише видалення із співтовариства інших в'язнів через міркування безпеки, дисципліни або захисту не становить нелюдського або такого, що принижує гідність, покарання (рішення у справі «Ramirez Sanchez v. France» від 06.07.2006). 
Важливо, що тягар доведення правомірності дій публічних осіб, які заподіяли шкоду особі під час затримання, арешту чи тримання під вартою, покладається на органи державної влади, адже саме вони мають надати задовільні та переконливі пояснення (рішення у справах «Рібіч проти Австрії» (Ribitsch v. Austria) [20] від 04.12.1995, «Салман проти Туреччини» (Salman v. Turkey) [23], заява № 21986/93, п. 100, ECHR 2000-VII). Органи державної влади повинні вживати всіх заходів для отримання всіх наявних доказів, які мають відношення до події, inter alia, показань очевидців та експертних висновків тощо. Будьякі недоліки в розслідуванні, які підривають можливість встановлення в ході розслідування причин заподіяння ушкоджень або винних осіб, ставлять під сумнів дотримання цього стандарту та вимог оперативності й розумної швидкості, які також передбачаються в цьому контексті (рішення у справі «Савіцький проти України» від 26.10.2012). При тому виправдання в національному суді публічних осіб, як і заподіяли катування чи нелюдського або такого, що принижує гідність, поводження чи покарання, не звільняє державу від відповідальності за статтею 3 Конвенції (рішення у справі Чолак та Філізер проти Туреччини (Colak and Filizer v. Turkey) [40] від 08.01.2004).

Міжнародні механізми попередження катувань i нелюдського і такого, що принижує гідність, поводження або покарання включають:

Конвенцію проти катувань та інших жорстоких, нелюдських або таких, що принижують гідність, видів поводження і покарання, до якої Україна приєдналась 26 січня 1987 р. (далі - Конвенція проти катувань), Факультативний протокол до Конвенції проти катувань, до якого Україна приєдналась 21 липня 2006 р. (далі Протокол до Конвенції проти катувань);

Комітет проти катувань, створений на підставі Конвенції проти катувань, Підкомітет ООН із питань 
Права людини в Україні та у зарубіжних країнах:

проблеми теорії та нормативно-правової регламентації

запобігання катуванням та іншим жорстоким, нелюдським або таким, що принижують людську гідність, видам поводження або покарання, створений на підставі Протоколу до Конвенції проти катувань.

Європейський механізм попередження катувань i нелюдського і такого, що принижує гідність, поводження або покарання включає:

Конвенцію про захист прав людини і основоположних свобод, яка містить імперативну норму про заборону катування нелюдського чи такого, що принижує гідність, поводження або покарання (стаття 3);

Європейську конвенцію про запобігання катуванням чи нелюдському або такому, що принижує гідність, поводженню чи покаранню (ратифікована Україною 24 січня 1997 р.);

Європейський комітет із питань запобігання катуванням чи нелюдському або такому, що принижує гідність, поводженню чи покаранню, який шляхом інспекцій перевіряє поводження 3 позбавленими волі особами з метою посилення, в разі необхідності, захисту таких осіб від катувань чи нелюдського або такого, що принижує їхню гідність, поводження чи покарання;

ЄСПЛ, який розглядає заяви щодо порушення державою статті 3 КЗПЛ.

Абсолютний характер гарантій, передбачених ст. 3 КЗПЛ, означає, що стосовно цього права не може бути жодних винятків і не може існувати жодних підстав для відступу держави від своїх зобов'язань за ст. 3 Конвенції про захист прав людини та основоположних свобод під час війни або іншої надзвичайної ситуації, що загрожує життю нації. Такий характер цієї заборони підкріплюється тим фактом, що дії, які ставляться у провину потерпілому, якими б неприйнятними чи небезпечними вони не були, жодним чином не можуть виправдати будь-яке посягання на гідність, свободу та фізичну недоторканність людини.

Заборона тортур i нелюдських або таких, що принижують гідність, видів поводження чи покарання $\epsilon, \mathrm{y}$ 
світлі рішень ЄСПЛ, однією з фундаментальних цінностей демократичного суспільства, а держава не має право ухилятися від його дотримання навіть у разі війни або іншої загальної небезпеки, яка загрожує життю народу.

Так, у справі «Томасі проти Франції» (Tomasi v. France) [31] від 27.08.1992 ЄСПЛ зазначив, що потреби слідства, а також труднощі в боротьбі зі злочинністю не можуть впливати на обмеження тілесної недоторканності підозрюваного навіть тоді, коли він підозрюється у тероризмі. Розглядаючи в цьому дусі справу «Чахал проти Великої Британії» (Chahal v. United Kingdom) [34] від 15 листопада 1996 року, Європейський суд зазначив, що усвідомлює труднощі, 3 якими в даний час стикаються держави, захищаючи суспільство від насильства терористів. Однак навіть у таких випадках Конвенція про захист прав людини та основоположних свобод забороняє в абсолютному порядку катування, нелюдське або таке, що принижує гідність, поводження чи покарання.

Національний механізм попередження катувань i нелюдського і такого, що принижує гідність, поводження або покарання містить:

- конституційне закріплення поваги до людської гідності, неприпустимості катування, жорстокого, нелюдського та такого, що принижує гідність особи, поводження чи покарання (стаття 28 Конституції України);

- галузеві механізми захисту честі та гідності людини. Цивільно-правовий механізм захисту честі та гідності людини включає право фізичної особи на звернення до суду з позовом про захист гідності та честі, а також ділової репутації (статті 297-299 ЦК України) [33]. Кримінальноправовий механізм запобігання посяганням на людську гідність включає заборону катувань (стаття 127 КК України), а також інститут покарання за злочини проти волі, честі та гідності людини [9];

- Національний превентивний механізм, створений на виконання положень Протоколу до Конвенції проти катувань у форматі «Омбудсмен +», який включає: 
Департамент НПМ як структурний підрозділ Секретаріату Уповноваженого Верховної Ради України з прав людини; регіональних представників Уповноваженого; Експертну раду з питань реалізації національного превентивного механізму; неурядові правозахисні організації, відібрані Уповноваженим для здійснення окремих функцій НПМ; моніторів (індивіди, які беруть участь у моніторингових візитах від громадськості). Головна ідея національного превентивного механізму полягає в запровадженні системи регулярних, незалежних відвідувань будь-якого місця, що перебуває під юрисдикцією та контролем держави, де утримуються чи можуть утримуватися особи, позбавлені волі, за розпорядженням державного органу чи за його вказівкою, або з його відома чи мовчазної згоди.

\section{4. Права на свободу і особисту недоторканність:}

\section{поняття, зміст, нормативне закріплення}

Серед особистих прав, що забезпечують природне існування людини, важливу роль відіграють права на свободу та особисту недоторканність.

Права на свободу та особисту недоторканність - це особисті суб’єктивні права людини, які означають фізичну свободу іï існування, можливість діяти на власний розсуд, не порушуючи при тому прав і свобод інших людей та не посягаючи на правопорядок.

Зміст цих прав полягає в такому:

- заборона будь-якої форми особистої залежності, зокрема, рабства і подібних до нього інститутів (боргова кабала, кріпацтво, насильницьке одруження, фізична передача людини іншій особі у спадок, за плату або без такої);

- заборона свавільного позбавлення волі та насильницького зникнення людини, а також право людини бути звільненою в певний термін у разі затримання, арешту або позбавлення волі, які здійснено правомірно;

- тілесна, статева і психологічна недоторканність, а саме: захищеність від будь-якого протиправного посягання 
на тілесну цілісність та здоров’я людини, її статеву свободу та свободу волі.

Варто зауважити, що права на свободу та особисту недоторканність не $\epsilon$ абсолютними. Міжнародні та національні акти щодо прав людини містять вичерпні переліки обставин, які уможливлюють обмеження прав людини на свободу та особисту недоторканність.

На міжнародному рівні право на свободу і особисту недоторканність проголошено статтею 3 ВДПЛ.

Стаття 9 МПГП деталізує зміст цих прав та правомірне їх обмеження. Нікого не може бути піддано свавільному арешту чи триманню під вартою чи позбавлено волі інакше, як на підставах і відповідно до такої процедури, які встановлено законом. Кожному заарештованому мають бути повідомлено пыд час арешту причини його арешту і в терміновому порядку пред'явлено обвинувачення. Кожна заарештована або затримана за кримінальним обвинуваченням особа в терміновому порядку доставляється до суду, має право на судовий розгляд протягом розумного строку або право на звільнення. При цьому ст. 10 зазначає, що всі особи, позбавлені волі, мають право на гуманне поводження і повагу людської гідності. А ст. 11 виключає можливість позбавлення волі з підстави невиконання особою договірного зобов'язання.

На європейському рівні права на свободу та особисту недоторканність визначено статтею 5 КЗПЛ, яка грунтується на принципі презумпції свободи людини, а саме: нікого не може бути позбавлено свободи, крім таких випадків і відповідно до процедури, встановленої законом, а також визначає виключні випадки позбавлення свободи. Стаття 5 КЗПЛ містить вичерпний перелік випадків правомірного обмеження права на свободу:

«1) законне ув'язнення особи після засудження іiі компетентним судом; 
Права людини в Україні та у зарубіжних країнах:

проблеми теорії та нормативно-правової регламентації

2) законний арешт або затримання особи за невиконання законного припису суду або для забезпечення виконання будь-якого обов'язку, встановленого законом;

3) законний арешт або затримання особи, здійснене 3 метою допровадження їі до компетентного судового органу за наявності обгрунтованої підозри у вчиненні нею правопорушення або якщо обгрунтовано вважається необхідним запобігти вчиненню нею правопорушення чи їі втечі після його вчинення;

4) затримання неповнолітнього на підставі законного рішення 3 метою застосування наглядових заходів виховного характеру або законне затримання неповнолітнього 3 метою допровадження його до компетентного органу;

5) законне затримання осіб для запобігання поширенню інфекційних захворювань, законне затримання психічнохворих, алкоголіків або наркоманів чи бродяг;

6) законний арешт або затримання особи 3 метою запобігання ії̈ недозволеному в'їзду в країну чи особи, щодо якої провадиться процедура депортації або екстрадиції».

ЄСПЛ, з'ясовуючи наявність чи відсутність порушення 3 боку держави статті 5 КЗПЛ, насамперед з'ясовує, чи відповідає Конвенції національний закон, за яким було здійснено обмеження чи позбавлення волі людини i, зокрема, чи відповідають їй загальні принципи закону, зокрема загальний принцип юридичної визначеності. Національний закон, який передбачає можливість позбавлення свободи, має бути доступним, чітко сформульованим і передбачуваним у своєму застосуванні для того, аби особа, отримавши за необхідності юридичну консультацію у справі, могла передбачити з розумним для певних обставин ступенем визначеності, ті наслідки, які може потягнути за собою конкретна дія (рішення у справі «Стіл та інші проти Великої Британії» («Steel and Others v. the United Kingdom») [30] від 23.09.1998).

Затримана чи взята під варту особа має право на перевірку дотримання процесуальних і матеріальних 
вимог, необхідних для законності позбавлення їі свободи (рішення у справі «Ніколова проти Болгарії» «Nikolova v. Bulgaria» [22] від 25.03.1999).

У рішенні у справі «Амуур проти Франції» («Amuur v. France») від 25.06.1996 Суд вказав, що для визначення правомірності позбавлення волі слід враховувати також такі критерії: вид, тривалість, наслідки і умови виконання заходу з позбавлення волі.

У справах щодо України ЄСПЛ визнавав порушення пункту 1 статті 5 КЗПЛ у випадках, коли адміністративний арешт, який формально підпадає під дію пункту 1(а) статті 5, використовувався для забезпечення перебування особи під вартою для інших цілей; або коли не існувало жодних законодавчих положень (у КПК чи інших нормативно-правових актах), які б передбачали, навіть шляхом посилання, процедуру щодо тримання особи під вартою 3 метою екстрадиції або застосування інших міжнародно-правових заходів правової допомоги у кримінальних справах; коли тримання особи під вартою не переслідувало жодну мету, зазначену в пункті 1 статті 5 Конвенції, i, отже, порушило вимоги цієї статті (наприклад, протягом періоду, коли щодо особи не було скасовано рішення про надання статусу біженця, а національне законодавство забороняло вислання біженців із території України, або коли затримання неповнолітніх заявників не підпадає під виняток, передбачений пунктом 1(d) статті 5 за відсутності підстав вважати, що на цю справу поширюються будь-які інші винятки, передбачені статтею 5 Конвенції). У низці справ щодо України було констатовано порушення пункту 1 (f) статті 5 Конвенції у зв'язку з тим, що національне законодавство не передбачає процедури, достатньо доступної, чітко сформульованої і передбачуваної у своєму застосуванні - такої, яка давала б змогу уникнути ризику свавільного тримання під вартою в очікуванні на екстрадицію [32].

Рішення ЄСПЛ у справі «Будан проти України» [25] від 14.01.2016 року звертає увагу на необхідність врахування 
віку затриманої за підозрою у вчиненні злочину особи. Зокрема, було констатовано порушення пункту 1 статті 5 КЗПЛ через те, що органами влади не було розглянуто можливість передачі неповнолітнього затриманого під нагляд батьків.

Зі змісту права на свободу та особисту недоторканність випливає низка обов'язків держави в разі втручання ії органів у свободу та особисту недоторканність осіб, зокрема: знати про місце знаходження особи, якщо вона була взята під варту органами влади; надати інформацію стосовно місця знаходження цієї особи; вжити ефективних заходів для гарантованого запобігання ризику зникнення людей.

Для правильного розуміння цих обов'язків держави варто звернутись до кількох рішень Європейського суду з прав людини. Зокрема, це рішення у справі «Кіпр проти Туреччини» («Cyprus v. Turkey») [26] від 10.05.2001 p. Обставини справи пов'язані 3 фактичною окупацією турецькими військовими північної частини Республіки Кіпр (1974) та проголошенням Турецької Республіки Північний Кіпр (1983, незалежність ТРПК не визнана жодною країною, крім Туреччини). Кіпр як державазаявниця зазначала, що саме Туреччина несе відповідальність за порушення прав людини на окупованій нею території Кіпру. Туреччина заперечувала свою відповідальність за порушення прав людини у Північному Кіпрі, стверджуючи, що ТРПК була незалежною державою, на яку не поширюється юрисдикція Туреччини. ЄС ыз прав людини постановив, що факти, стосовно яких було подано скарги, підпадають під юрисдикцію Туреччини. Зокрема, Туреччина несе відповідальність за нездатність власних органів влади провести ефективне розслідування щодо місцезнаходження і долі зниклих безвісти греків-кіпріотів за обставин, що загрожують життю.

Важливим $\epsilon$ процесуальний аспект цих обов'язків держави. У рішенні по справі «Курт проти Туреччини» («Kurt v. Turkey» від 25.05.1998) [28] суд встановив, що 
відсутність документальної фіксації таких відомостей, як дата, час і місце затримання особи, їі ім'я, підстави для затримання та ім'я особи, яка здійснює затримання, має вважатися таким, що суперечить вимозі законності і самій меті ст. 5 КЗПЛ.

На національному рівні право на свободу та особисту недоторканність закріплено статтею 29 Конституції України, в якій встановлено критерії правомірності обмеження свободи та недоторканності особи:

1) підстави та порядок тримання під вартою встановлюються законом;

2) нагальна необхідність запобігти злочинові чи його перепинити;

3) невідкладне повідомлення особі про мотиви арешту чи затримання, роз'яснення його/ії прав та надання можливості з моменту затримання захищати себе особисто та користуватися правничою допомогою захисника;

4) тимчасовий характер тримання особи під вартою. Обгрунтованість цього запобіжного заходу протягом сімдесяти двох годин має бути перевірена судом;

5) вмотивоване рішення суду про тримання під вартою;

6) негайне звільнення з-під варти, якщо протягом сімдесяти двох годин із моменту затримання особі не вручено вмотивованого рішення суду.

Законність затримання та застосування запобіжних заходів щодо підозрюваних, обвинувачених осіб конкретизується положеннями Глави 18 «Запобіжні заходи, затримання особи» КПК України.

\section{Висновки}

Права людини, що сформульовані в часи становлення першого їх покоління, полягають у праві на життя, на свободу, в тому числі й на право захищати її від посягань 3 боку держави, у прагненні до щастя, на сучасному етапі розвитку людства набули характеру особистих прав людини, якими $\epsilon$ закріплені об'єктивним правом 
Права людини в Україні та у зарубіжних країнах:

проблеми теорії та нормативно-правової регламентації

можливості фізичного існування, соціального буття i духовного розвитку індивіда. Вони $\epsilon$ виразом індивідуальності, автономії та свободи людини, і в цьому сенсі - «бар'єром» від посягань на індивіда з боку інших людей, суспільства та держави.

Особисті права людини традиційно розглядаються в контексті природно-правової теорії, адже такі права $\epsilon$ вираженням природи людини, що не залежать від формально-юридичного їх закріплення. До особистих прав людини, зважаючи на їхню природність, основоположність та невід'ємність, належать: право на життя; право на вільний розвиток; право на повагу до людської гідності; право на свободу та особисту недоторканність. Похідними від цих основоположних прав першого покоління виступають: право на недоторканність житла; право на таємницю листування, телефонних розмов, телеграфної та іншої кореспонденції; право на свободу пересування та вільний вибір місця проживання; право на свободу думки і слова, на вільне вираження своїх поглядів і переконань; право на свободу світогляду і віросповідання.

Особисті права людини, на відміну від усіх інших прав, можуть реалізовуватися людиною без будь-якого стороннього втручання чи допомоги і тому в системі відносин між індивідом та державою/публічною владою носять негативний характер, оскільки вимагають невтручання держави у сферу їх приватного життя. Для держави вони $є$ обмеженням, на що звертав увагу Адемар Есмен: держава має утримуватися від втручання в певні сфери, надаючи певний простір особистій діяльності [36]. Утім, реалізація людиною цих прав вимагає й виконання позитивних обов'язків із боку держави та інших агентів публічної влади, що закріплено на національному, регіональному європейському та міжнародному рівнях. Саме ці обов'язки держави/публічної влади зумовлюють створення та функціонування організаційно-правових механізмів захисту прав людини, серед яких чільне місце 
належить інституту омбудсмана, Європейському суду із прав людини, правозахисним структурам $00 \mathrm{H}$.

\section{Список використаних джерел:}

1. Антонович М. Україна в міжнародній системі захисту прав людини: монографія. Київ : Видавничий дім «KM Academia», 2000. 262 c.

2. Бисага Ю.М., Палінчак М.М., Бєлов Д.М., Данканич М.М. Права людини. Ужгород, 2003. 189 с.

3. Декларация о праве на развитие: Принята резолюцией 41/128 Генеральной Ассамблеи от 4 декабря 1986 г. URL: https://zakon.rada.gov.ua/laws/show/995_301.

4. Загальна декларація прав людини від 10 грудня 1948 p. URL: https://zakon.rada.gov.ua/laws/show/995_015.

5. Кожан В.В. Особисті права людини: загальнотеоретична характеристика : дис. ... канд. юрид. наук : спец. 12.00.01. Львів, 2016. 229 с.

6. Конвенція про захист прав людини і основоположних свобод від 11 листопада 1950 p. URL: https://zakon.rada.gov.ua/laws/show/995_004.

7. Конституція України: Прийнята на V сесії Верховної Ради України 28 червня 1996 р. Відомості Верховної Ради України. 1996. № 30. Ст. 141. URL: http://zakon2.rada.gov.ua/ laws/show/254\%D0\%BA/96-\%D0\%B2\%D1\%80.

8. Конституція України : Прийнята на V сесії Верховної Ради України 28 червня 1996 р.// Відомості Верховної Ради України. 1996. № 30. Ст. 141. URL: http://zakon2.rada.gov.ua/ laws/show/254\%D0\%BA/96-\%D0\%B2\%D1\%80.

9. Кримінальний кодекс України : Закон України від 5 квітня 2001 p. (зі змінами і доповненнями) URL: http://portal.rada.gov.ua.

10. Міжнародний пакт про громадянські і політичні права. URL: https://zakon.rada.gov.ua/laws/show/995_043.

11. Права і свободи людини і громадянина в Україні (доктрина Європейського суду 3 прав людини i Конституційного Суду України) : навчальний посібник. Київ : Юрінком Інтер, 2013. 376 с. 
12. Проблеми сучасної конституціоналістики: навч. посіб. / за заг. ред. А.Р. Крусян та А.А. Єзерова. Вип. 4: Конституційне гуманітарне право. Київ : Юрінком Інтер, 2018. 524 c.

13. Протокол № 13 до Конвенції про захист прав людини i основоположних свобод, який стосується скасування смертної кари за всіх обставин. URL: https://zakon.rada.gov.ua/laws/show/994_180.

14. Протокол № 6 до Конвенції про захист прав людини і основоположних свобод, який стосується скасування смертної кари. URL: https://zakon.rada.gov.ua/laws/show/ 994_802.

15. Пушкіна 0. Особисті права людини в конституційному законодавстві України. Юридична Украӥна. 2013. № 5. С. 17-24.

16. Рабінович П.М. Основоположні права людини: соціально-антропна сутність, змістова класифікація. Вісник Національної академії правових наук Украӥни. 2013. № 2(73). C. $10-15$.

17. Рабінович П.М., Хавронюк М.I. Права людини i громадянина: навч. посібник. Київ : Атіка, 2004. 464 с.

18. Размєтаєва Ю.С. Права людини як фундаментальна цінність громадянського суспільства : монографія. Харків : Финарт, 2013. 196 с.

19. Размєтаєва Ю.С. Доктрина та практика захисту прав людини: навчальний посібник. Київ : ФОП Голембовська 0.0., 2018. 364 c.

20. Рибич (Ribitsch) против Австрии. Решение ЕСПЧ от 4 декабря 1995 г. URL: http://www.echr.ru/documents/ doc/2461491/2461491.htm.

21. Рішення КСУ у справі за конституційним поданням 51 народного депутата України щодо відповідності Конституції України (конституційності) положень статей $24,58,59,60$, 93, 190-1 Кримінального кодексу України в частині, що передбачає смертну кару як вид 
покарання (справа про смертну кару). URL: https://zakon.rada.gov.ua/laws/show/v011p710-99.

22. Рішення у справі «Ніколова проти Болгарії» від 25 березня 1999 p. URL: https://zakon.rada.gov.ua/laws/show/ 980_404.

23. Рішення у справі «Салман проти Туреччини» від 04 грудня 1995 p. URL: http://search.ligazakon.ua/l_doc2.nsf/ link1/S02538.html.

24. Рішення у справі «Янков проти Болгарії» від 11 грудня 2003 p. URL: https://zakon.rada.gov.ua/laws/ show/980_213.

25. Справа «Будан проти України» від 14 січня 2016 р. URL: https://zakon.rada.gov.ua/laws/show/974_b06.

26. Справа «Кіпр проти Туреччини» (Case of Cyprus v. Turkey) від 10 травня 2001 p. URL: https://rm.coe.int/ $16806 \mathrm{~b} 5964$.

27. Справа «Корнейкова та Корнейков проти України» від 24 червня 2016 p.. URL: https://zakon.rada.gov.ua/ laws/show/974_b56.

28. Справа «Курт проти Туреччини» («Kurt v. Turkey») від 25 травня 1998 р. URL: http://europeancourt.ru/uploads/ ECHR_Kurt_v_Turkey_25_05_1998.pdf.

29. Справа «МакКанн та інші проти Сполученого Королівства». Рішення ЄСПЛ від 27 вересня 1995 року. C. 204-296. URL: http://aau.edu.ua/static/pdf/art2_judg1.pdf.

30. Справа «Стіл та інші проти Сполученого Королівства» (Case of Steel and others v. the United Kingdom) від 23 вересня 1998 p. URL: https://zakon.rada.gov.ua/laws/ show/980_106.

31. Томази (Tomasi) против Франции. Решение ЕСПЧ от 27 августа 1992 г. URL: http://europeancourt.ru/uploads/ ECHR_Tomasi_v_France_27_08_1992.pdf.

32. Фулей Т. Проблеми забезпечення права особи на свободу та особисту недоторканність: коментар до справи «Харченко проти України». Судова практика. 2012. № 1(115). C. 126-129. 
33. Цивільний кодекс України : Закон України від 16 січня 2003 p. URL: http://portal.rada.gov.ua.

34. Чахал против Соединенного Королевства. Решение ЕСПЧ от 15 ноября 1996 г. URL: https://precedent.in.ua/ 2016/04/08/chahal-protyv-soedynennogo-korolevst/.

35. Шукліна Н.Г. Конституційно-правове регулювання прав і свобод людини і громадянина в Україні (питання теорії і практики) : монографія. Київ : Центр навчальної літератури, 2005. 424 с.

36. Эсмен А. Общие основания конституционного права: пер. с 4-го франц. изд. под ред. Н.О. Бер. 2-е изд. Санкт-Петербург : Тип. О.Н. Попова, 1909. 461 с.

37. Case of Aydin v. Turkey. 25 Septemder 1997, European Court of Human Rights. The International Journal of Human Rights. Volume1, 1997. Issue 4. P. 86-89. URL: https://www.tandfonline.com/doi/abs/10.1080/1364298970 8406700 .

38. Case of Ireland v. the United Kingdom. Judgment 18 January 1978. URL: https://www.law.umich.edu/ facultyhome/drwcasebook/Documents/Documents/Republic \%20of\%20Ireland\%20v.\%20United\%20Kingdom.pdf.

39. Case Gulec v. Turkey. 27th July 1998, European Court of Human Rights. The International Journal of Human Rights. Volume 3, 1999. Issue 1. P. 110-112. URL: https://www.tandfonline.com/doi/abs/10.1080/1364298990 8406791? journalCode=fjhr20.

40. Case Colak and Filizer v. Turkey. 08.01. 2004. URL: https://www.hrr-strafrecht.de/hrr/egmr/96/32578-96.php3.

41. Wellman C. Solidarity, the Individual and Human Rights. Human Rights Quarterly. 2000. Volume 22, Number 3. P. 639-657. 